\title{
Výuka poezie a inspirace Cullerovou Teorií lyriky
}

Václav Jindráček

\begin{abstract}
Teaching Poetry and Inspiration by Culler's Theory of the Lyric

The paper refers to the responses to the Czech translation of Theory of the Lyric by Jonathan Culler and connects them with the research of teaching poetry in Czech schools. The main subject of interest is a case study of one lesson in a Czech secondary school. During the lesson, the validity of some of Jonathan Culler's theories is demonstrated. Consequently, it turns out that inspiration by Culler's theory also means a return to several famous considerations of theorists such as Zdeněk Kožmín or Miroslav Červenka.
\end{abstract}

\section{KEYWORDS}

Teaching Poetry; Lyric; Jonathan Culler; Zdeněk Kožmín; Interpretation; Pedagogical Research; Case Study.

\section{KLÍčOVÁ SLOVA}

Výuka poezie; lyrika; Jonathan Culler; Zdeněk Kožmín; interpretace; pedagogický výzkum; případová studie.

Poezie nemá v českých školách zrovna na růžích ustláno. $\mathrm{K}$ tomuto snad až přespř́iliš lakonickému a př́krému konstatování mě přiměl ohlas na nedávno vydaný český překlad Teorie lyriky Jonathana Cullera (CULLER 2020). Kniha, která završuje jednu podstatnou část dlouholeté vědecké a pedagogické práce amerického literárního teoretika, totiž v poměrně krátké době přinesla několik zajímavých podnětů nejen pro české myšlení o poezii, ale rovněž k úvaze nad podobou školní výuky literatury (MÁCL 2020, MARKOVÁ 2020b, KRÁLÍKOVÁ 
2021). Už v doslovu k jejímu českému vydání konstatoval Josef Hrdlička, že Cullerova práce je čtivým uvedením do problematiky lyrické poezie, jaké v českém prostředí citelně chybí a které se nespokojuje s nějakou „přísnou esencialistickou definicí" lyriky či poezie a s představou, že jednota žánru je otázkou jednou provždy uzavřenou. ${ }^{1}$ A podle Ondřeje Mácla, autora jedné z recenzí překladu Cullerovy práce, není kniha namířena ani tak proti jiným podobně komplexním teoriím jako především proti způsobu, jak se poezie učí ve školách. Slovy autora recenze: „Známe to i z České republiky, že původ literárně-teoretických nástrojů užívaných v pedagogické praxi lze vystopovat až někam k Josefu Jungmannovi“ a „množství pedagogů jej raději přejímá jako jednou dané dědictví“ a jako „posvěcený“, dost těžko proměnitelný „obsah výkonu své práce“ (MÁCL 2020).

Fakt, že se Cullerova kniha záhy po svém prvním vydání (v roce 2015) stala často citovaným (podle Josefa Hrdličky až „autoritativním“) textem, ${ }^{2}$ tak podle mého soudu přesvědčivě dokazuje, jak naléhavé je volání po ucelené teorii, která je schopna dostatečně objasnit, proč je užitečné prověřovat ustálené způsoby nazírání na poezii a proč se ve školách (a nejen v nich) vyplatí číst básně s chutí a s potěšením, bez nutkavé potřeby hledat (či spíše dopodrobna „luštit“) jejich „jednoznačná“ sdělení. A potřeba takové teorie se rovněž shoduje s výsledky výzkumů, které v posledních letech několikrát potvrdily, že hodiny literatury jsou nejen $\mathrm{v}$ českých, ale i v zahraničních školách poznamenány neodůvodněným ostychem, či přímo „strachem z poezie“. ${ }^{3}$ Podle aktuálních výzkumů čtenářství totiž příslušníci dnešní mladé generace dávají opakovaně najevo, že se o poezii nezajímají, a když už se s ní ve škole setkají, zpravidla jim je spíše „esencí povinnosti“ než zdrojem potěšení a zájmu (TRÁVNÍČEK 2017: 152-153). Mnozí $\mathrm{z}$ nich vidí $v$ poezii jen komplikované sdělení něčeho, co by šlo vyjádřit jinak, přímo a jednoznačně (VALA 2013: 12). A leckteří mají pocit, že je básnické slovo až př́liš exkluzivní na to, aby na ně zapůsobilo a niterněji je obohatilo (TRÁVNÍČEK 2017: 167).

Úskalí formalismů, které mohou poznamenat čtenářský vztah k poezii, jsem měl možnost poznat i v průběhu výzkumu vyučovacích hodin na základních a středních školách, které jsem pravidelně navštěvoval od roku 2013 a v nichž

1) Třeba právě s takovou představou, která se - jak píše Josef Hrdlička - uplatňuje v českých školách, kde stále přeživá model lyriky jako jednoho ze tř́ literárních druhů (či základních žánrů): „Tato triáda [lyrika, epika, drama] má své počátky u autorů 18. a 19. století a odpovídá doznívající konstelaci žánrů, která se v teoretickém diskursu držela díky tradičnímu hodnocení žánrư" (HRDLIČKA 2020: 433).

2) Srov. HRDLIČKA 2020: 431. Jen v citační databázi Scopus je do roku 2021 uvedeno přes 200 ohlasů na Cullerovu knihu.

3) Pro označení „strachu z poezie“ se v zahraničí užívá dokonce zvláštního slova - „metrofobie“ (TIMOTHY 2018, LESSLEY 2014). 
jsem sledoval, jak se učitelé společně s žáky zaobírají různými básnickými texty. ${ }^{4}$ Pro účely disertační práce (JINDRÁČEK 2015), která byla zaměřena na analýzu výuky epické a lyrickoepické poezie, jsem nejdříve (v letech 2013 a 2014) navštěvoval vyučovací hodiny tři učitelek (s praxí 2 roky, 10 let a 21 let) a jednoho učitele (s čtyřletou praxí) na čtyřech základních školách. ${ }^{5}$ A se zkušenostmi, které se mi v těchto hodinách podařilo získat, jsem se v roce 2015 rozhodl, že budu zjištovat, zda se obdobné situace dají zaznamenat také na školách středních - kde jsem v průběhu šesti let spolupracoval s dvěma učiteli (s praxí 7 a 12 let) a dvěma učitelkami (15 a 36 let praxe). S časem stráveným zúčastněným pozorováním výuky (a jejím srovnáváním se závěry aktuálních teoretických a výzkumných publikací ${ }^{6}$ - mimo jiné právě s Cullerovou Teorií lyriky) jsem se tak stále silněji utvrzoval v přesvědčení, že leckterá povrchní a spekulativní tvrzení, jež posilují tradované předsudky k četbě básní, se v hodinách literatury ustavičně opakují bez ohledu na to, zda jde o výuku na základní nebo na střední škole. A průběžně jsem si ověřoval, že různé povrchní a nepodložené výroky o básních zdaleka nepronášejí jen učitelé, kteří se o poezii nezajímají, ale paradoxně i ti, kteři ji rádi čtou a ve výuce se jí pravidelně věnují.

Vzpomínám si na osobní rozhovory s učiteli, kteří mi zcela intuitivně a se silným zaujetím vyprávěli, co všechno pro ně poezie znamená a s jakou radostí se vracejí k tvorbě svých milovaných básníků:

„Poezii prostě zbožňuju. Třeba Erben, to je báječný. Jak ty verše krásně zní. A jak je to jednoduše napsaný. A přitom vím, že v nich příště zase něco nového najdu a že mě zase něčím překvapí

(učitelka střední odborné školy, 62 let, 36 let pedagogické praxe).

A stejně tak si vybavuji desítky vyučovacích hodin, v nichž dialog o poezii nebyl ničím jiným než letmou parafrází několika přečtených veršů nebo formálním výčtem použitých jazykových a veršových prostředků:

4) Data, o něž se opírám, tvoří především zvukové záznamy vyučovacích hodin a př́ležitostných rozhovorů, které jsem s učiteli vedl. Veškerý zvukový materiál jsem s pomocí dvou spolupracovníků přepsal do textové podoby a obohatil jej o vlastní terénní zápisky, pořízené v průběhu zúčastněného pozorování výuky.

5) Kritéria výběru účastníků výzkumu jsem podrobněji popsal v disertační práci (JINDRÁČEK 2015: 178-184). Šlo mi především o situace v běžných školách - tj. v těch, které nejsou spjaty s alternativními školskými koncepty (jako jsou daltonský plán nebo walfdorská škola) a jejichž vzdělávání má podle závěrů zpráv České školní inspekce „velmi dobrou“ nebo „standardni““ („požadovanou“, „průměrnou“ či „spíše nadprůměrnou“) kvalitu. Do výběru tak nebyly zařazeny školy s vynikajícími („výrazně nadprůměrnými“) nebo naopak nedostatečnými („podprůměrnými“) výsledky vzdělávání a výchovy.

6) Z českých prací např́iklad VALA 2013, HNÍK 2014, ŘEŘICHOVÁ - VALA - SLADOVÁ, 2014. Ze zahraničních publikací: PIKE 2000, PESKIN 2007, EVA-WOOD 2008. 
Václav Jindráček

Výuka poezie a inspirace Cullerovou Teorií lyriky

Karel Jaromír Erben, Kytice - interpretace a charakteristické znaky

(pracovní list pro žáky 2. ročníku střední odborné školy)
1. Kolik básní je obsaženo ve sbírce Kytice?
2. Vyber si jednu báseň a napiš její název.
3. Vyjmenuj hlavní postavy.
4. Jaký vztah je popisován mezi postavami?
5. Najdi 3 lyrické prvky v básni.
6. Najdi epický prvek v básni.

7. Jaký rým se v básni objevuje?

8. Uved’ 2 př́klady personifikace.

9. Uved' 2 pŕíklady metafory.

10. Uved' 3 př́klady archaických slov.

11. Který slohový útvar báseň připomíná?

12. Kdo je hlavní postavou ve většině básní?

(Úlohy vytvořené toutéž učitelkou).?

Korpus dat (terénních zápisků a zvukových nahrávek výuky), který se mi za několik let podařilo shromáždit, ${ }^{8}$ vedl tedy mou pozornost často právě $\mathrm{k}$ tomu, čím se zabývaly zmíněné pedagogické nebo čtenářské výzkumy, a umožňoval mi v reálné praxi poznat řadu témat, s nimiž jsem se nejednou setkal v knize Jonathana Cullera nebo v reakcích, jež Cullerova kniha vyvolala. Zkušenosti, které jsem ve školách získával, totiž přede mnou rozkrývaly situace, které se pohybovaly až v pozoruhodně širokém rozpětí. Jeden okraj tohoto pomyslného spektra tvořily povrchní, ustálené a zavádějící soudy o poezii, mnohdy vyvolané potřebou vytvořit představu o dosažitelnosti přesné a doslovné kategorizace básnické tvorby. ${ }^{9} \mathrm{~A}$ na opačné straně se ocitaly výroky, které se těmto vžitým představám vzpíraly a dokazovaly, jak marné je doufat, že by takové stereotypní zacházení s textem mohlo žáky inspirovat, aby poezii četli, oceňovali ji a nacházeli v ní zalíbení. ${ }^{10}$

Materiál, který jsem ve školách získal, chci proto v následujícím textu představit alespoň několika ukázkami. Na úryvcích z přepisu jedné zaznamenané

7) Úlohy byly využity v jedné z hodin zaznamenaných na střední odborné škole. Je přitom paradoxní, že jednotlivé otázky a úkoly - i když se zjevně spoléhají jen na povrchní výčet několika nesouvislých jevů - nejsou v rozporu $\mathrm{s}$ „výsledky vzdělávání“ uvedenými v „rámcových vzdělávacích programech středního odborného vzdělávání“. Jak je z titulu pracovního listu zřejmé, sama učitelka byla přesvědčena, že právě takto lze žáky motivovat, aby text „interpretovali“ a vystihli jeho „charakteristické znaky“, tj. splnili výsledky předepsané v kurikulu: „žák vystihne charakteristické znaky různých literárních textů a rozdíly mezi nimi; text interpretuje a debatuje o něm“.

8) Konkrétně se jedná o přepis zvukových nahrávek 61 vyučovacích hodin, které jsem sledoval v letech 2013 a 2014 ve čtyřech základních školách v Ústeckém a Karlovarském kraji (31 hodin na druhém stupni, u žáků ve věku od 11 do 15 let) a mezi lety 2015 a 2021 ve výuce na středních školách v Ústeckém, Středočeském a Zlínském kraji (30 hodin ve dvou středních odborných školách, na gymnáziu a středním odborném učilišti).

9) Tj. ustálené a zavádějící soudy, před nimiž varuje také Culler, když upozorňuje na rizika těch situací, které od čtenáře vyžadují, aby $\mathrm{k}$ poezii přistupoval obdobně jako k vyprávění příběhu a v každé básni hledal mluvčího pochopitelného jako postavu v románu (CULLER 2020: 18).

10) Což zdůrazňuje Culler např́iklad už v předmluvě k českému vydání, kde konstatuje: „Mohu jen doufat, že seznámení s Teorií lyriky čtenáře pobídne, aby [...] nepředpokládali, že básně jsou objekty určené k interpretaci, nýbrž hledali přístupy k potěšení z jejích rytmů, zvukových vzorců, verbálních her či imaginativní energie“ (CULLER 2020: 12). 
vyučovací hodiny, která mi poslouží jako případová studie, ${ }^{11}$ se pokusím objasnit, o čem mohou taková data vypovídat. A na základě srovnání těchto dat $\mathrm{s}$ vybranými tématy Cullerovy knihy (a ohlasů na ni) budu hledat odpověd' na otázku, proč je užitečné zjištovat, jak se $\mathrm{v}$ českých školách čte poezie a za jakých okolností se stává obsahem vzdělávání.

\section{Být čtenářem poezie}

„Višs, já miluju hlavně Václava Hraběte. Ten je úžasný, že? Někdy vlastně není nutný rozebírat to a to, ale prostě se začíst, zaposlouchat, slyšet tu melodii, vidět verše před sebou. A vzpomenout si na ně“ (učitelka střední odborné školy, 62 let, 36 let pedagogické praxe). ${ }^{12}$

Citovaná promluva se mi vybavila jako nanejvýš vhodný příklad těch situací, které dokážou docela dobře ilustrovat, jak si básně vydobývají naši pozornost a získávají si ji natolik, že si mnohé verše - třeba i po letech - uchováváme v paměti, vracíme se $\mathrm{k}$ nim a oživujeme si je. Ostatně podobné výroky čtenářů, kteři promlouvali o svém vztahu k poezii, zaznamenal také Jiří Trávníček v knize Česká čtenářská republika (2017). Ukázal zde, že poezie se do průzoru čtenářů dostavuje zpravidla tehdy, když si najdou osobní vztah k určitému básnickému dílu, třeba i navzdory zážitkům z dob školní výuky, kdy jim byly básně podsouvány pouze jako povinnost či úkol (TRÁVNÍČEK 2017: 168). Což pochopitelně neznamená, že by ve škole nemohly nastat situace, které by byly s to pobídnout žáky $\mathrm{k}$ zájmu o poezii. Výpovědi čtenářů v Trávníčkově knize svědčí dokonce o tom, že $\mathrm{k}$ básním dokáže člověka přivést dost často právě učitel. Podstatné však je, že takový zájem - alespoň podle výroků v uvedené knize - učitelé jen sotva probudí tím, když z poezie činí rutinu a povinnost. A mnohem spíše jej dokážou vyvolat, když si své žáky získávají vlastním, osobitým čtenářským zaujetím.

Promluvu, kterou jsem zkraje této části textu uvedl, se mi podařilo zaznamenat krátce předtím, než jsem navštívil vyučovací hodinu, která se před několika lety uskutečnila ve třídě žáků druhého ročníku střední odborné školy a kterou vedla jedna z účastnic mého výzkumu - učitelka češtiny s dlouholetou

11) V souladu s doporučením základních metodologických příruček k realizaci případových studií (srov. BASSEY 1999, YIN 2003) mi šlo především o reprezentativní případ, který vyhovuje kritériím tzv. typické školy (v mém případě takové školy, kde lze očekávat běžné situace týkající se výuky poezie).

12) V souladu s etickými požadavky na zachování důvěrnosti jsou data anonymní - resp. všechna jména učitelů i žáků jsou v textových materiálech nahrazena pseudonymy. 
pedagogickou praxí. ${ }^{13}$ Ještě před vyučovací hodinou jsem si přitom s kolegyní promluvil nejen o tématu, jemuž se hodlala s žáky věnovat, ale také o jejích vlastních čtenářských zkušenostech s poezií. Úryvek Hrabětovy básně se jí tak opakovaně stával podnětem $\mathrm{k}$ promluvám, které $\mathrm{v}$ průběhu rozhovoru navozovaly dojem, že nejsou ani tak výpovědí učitelky o tématu výuky jako spíše svědectvím čtenářky poezie o návratu k obdivovanému dílu uznávaného autora. $\mathrm{Z}$ mnoha jejích výroků se totiž zdálo, jako by se $\mathrm{k}$ Hrabětově poezii vracela nikoli proto, aby z ní učinila obsah školního vzdělávání, ale z toho důvodu, aby vyjádřila své nepřetržité okouzlení textem a aby náležitě vysvětlila, proč právě tyto verše poutají její pozornost:

„Je to úžasné, opravdu úžasné. Je to báseň, která mě vždycky dostane. Stačí si vzpomenout na pár řádků. Jen tak si vzpomenout na několik veršů."

Když učitelka svolila, abych z našeho dialogu pořídil zvukovou nahrávku, nemohl jsem ještě tušit, jak cenný materiál získám. Teprve po několika letech - se zkušenostmi nastřádanými $\mathrm{v}$ průběhu pozorování výuky $\mathrm{v}$ nejrůznějších školách - jsem tehdejší rozhovor začal posuzovat v nových souvislostech. V desítkách vyučovacích hodin, jichž jsem se za tu dobu zúčastnil, se mi totiž témata rozhovoru vybavovala tak často, že jsem se k nim musel znovu vracet a pátrat po tom, která z nich se nějak odrážejí ve školské praxi. A mnohé ze situací, jimž jsem byl přítomen - a které se leckdy až nápadně podobaly sobě navzájem, třebaže se odehrály ve výuce různých učitelek i učitelů na různých typech škol -, mě inspirovaly $\mathrm{k}$ tomu, abych výpovědi čtenářky Hrabětovy poezie důkladněji srovnal také s průběhem vyučovací hodiny, která následovala po uskutečnění tehdejšího rozhovoru a jejímž tématem se měla stát právě jedna z básní Václava Hraběte.

\section{Volba úryvku}

Text, jemuž se tenkrát žáci měli věnovat, byl úryvkem z Hrabětovy Básně skoro na rozloučenou:

13) První hodinu učitelky Jany jsem měl možnost zhlédnout v roce 2015 - krátce poté, co jsme se jako kolegové češtináři seznámili na metodickém semináři určeném učitelům základních a středních škol. Naše spolupráce pak trvala několik let: až do roku 2019 jsem průběžně navštěvoval její hodiny věnované poezii a se svolením učitelky, žáků i ředitele školy jsem z pozorovaných hodin pořizoval nahrávky, které se staly součástí materiálu analyzovaného v tomto článku. 
„Slunce

překrásný manekýn

se prkenně uklání

k západu

Zavírají se

květiny a obchody

Praha unavená

chválou básníků a svojí

krásou

šediví

soumrakem

Je to tak podivné

Co všechno se ti podobá

Je to tak podivné

Ta myšlenka že tě můžu ztratit

Protože všechno na světě se neustále mění

Můžu tě ztratit

a zase budou rána

plná cigaret

a bude to svádět

ke krásnému a pompéznímu smutku

Můžu tě ztratit

a zase budou noci

měsíc vlající na obloze bude podobný stínu

tvých rozpuštěných vlasů

nebudu moct spát a budu nenávidět

klasiky

Můžu tě ztratit“

(HRABĚ 1990: 45-46).

Poetizace zdánlivě těch nejprostších životních jevů či okamžiků v této básni navozuje dojem, jako by slunce i město ožívaly a stávaly se aktéry potemnělé scenérie s konkrétními městskými detaily („Slunce překrásný manekýn / se prkenně uklání k západu“, „zavírají se květiny a obchody“ a Praha „šediví 
soumrakem“). Na totéž upozornila vlastně i sama učitelka, když jsem s ní vedl rozhovor:

„Když si jen člověk přečte ty verše: slunce je překrásný manekýn. To je, jako když si člověk představí živé bytosti, jo, když se prkenně uklání, ta personifikace a taky protimluv.“

Její sdělení je však možné ještě doplnit. Personifikace totiž neposkytuje čtenáři žádný důvod k tomu, aby „slunce“ či „Prahu“ chápal jako symbolické bytosti, nebo dokonce jako postavy nějakého příběhu. A úvodní verše evokují spíše stř́idání či splývání vizuálně sugestivních výjevů, než aby navozovaly představu jasně ohraničeného prostoru, v němž se odehrávají určité události. Takového účinku dosahuje ostatně i strofa, která se koncentruje na prézens promluvy: oslovení blíže neurčeného protějšku („Je to tak podivné / co všechno se ti podobá") působí skoro jako osobní, meditativní zpověd', která poutá pozornost sama k sobě a - jak by řekl Jonathan Culler - neobsahuje žádné náznaky toho, že by se mělo jednat o promluvu nějaké fikční postavy, jejíž situaci je užitečné rekonstruovat či převyprávět. A nelze ani s jistotou říci, ke komu se taková slova obracejí - neurčitým „ty“ může být míněn čtenář, ale lze jej číst také jako oslovení blízkého člověka, nebo dokonce jako hlas, jejž si oslovený vybavuje a nese ve svém vlastním nitru. ${ }^{14}$ Zdá se tedy, že rozhodování o tom, kdo a ke komu v této básni mluví, nemusí mít pro čtenáře zdaleka takový přínos, jaký má zálibné (a zdánlivě bezúčelné) prodlévání nad těmi verši, které vyvolávají pocit, že nejsou časově ohraničeny a promlouvají k čtenáři v jeho př́tomnosti - jakoby právě v okamžiku, kdy se s nimi setkává („Je to tak podivné / co se ti podobá“).

Na pozvolný, až konejšivý a meditativní ráz básně přišla řeč také v rozhovoru, když kolegyně mluvila o verších, které $\mathrm{k}$ sobě strhávají pozornost několikerým opakováním slov „můžu tě ztratit“:

„A když tam opakuje několikrát to ,můžu tě ztratit‘, to je, jako by říkal, jo, bojím se, že tě ztratím, jako kdyby jen tak zůstával v určitém zamyšlení, ta myšlenka, že můžu tě ztratit.“

Opakující se verš je ve svých důsledcích mnohoznačný. Na první pohled by se mohlo zdát, že vyjadřuje stísněný pocit způsobený obavou z pomíjivosti života, vystaveného neúprosnému plynutí času (,Je to tak podivné / Ta myšlenka že tě můžu ztratit"), stejně tak ale může být čten jako smířené přijetíjistoty, že vše, co 
člověka obklopuje, je dočasné, nestálé a proměnlivé („Protože všechno na světě se neustále mění). Pro taková zjištění přitom rozhodně není bezvýznamné, když si čtenář všimne, že klíčovou složkou výsledného účinku je rytmičnost dosažená opakováním a variováním celých slov a slovních obratů. ${ }^{15}$ Meditativní ráz básnické výpovědi by byl totiž jen sotva tak efektní a podmanivý, kdyby prostřednictvím této rytmičnosti nenavozoval dojem, že vyslovený pocit je sice dočasný, ale zároveň se může kdykoli - vždy znovu a znovu - vracet.

Kdyby žáci měli možnost pokračovat v čtení Hrabětovy básně, spatřili by verše, které se $\mathrm{k}$ čtenáři obracejí snad ještě naléhavěji než text $\mathrm{v}$ dosavadních slokách. Mohli by vnímat jejich zvukomalebnost, jazykové bohatství (v slovníku se rozpínající od bezpříznakových slov až po výrazy provokativní, přízemní a nepoetické) ${ }^{16}$ a působivou rytmizaci, kterou text dosahuje zejména prostřednictvím nápadného opakování infinitivních vazeb. A naskytla by se jim příležitost, aby pocítili, že rytmizace rovněž strhává pozornost $\mathrm{k}$ veršům vyjadřujícím touhu a odhodlání zachovat to, co tvoří opravdové hodnoty - ony „lehkomyslné nevychované a pravdivé děti naší lásky“:

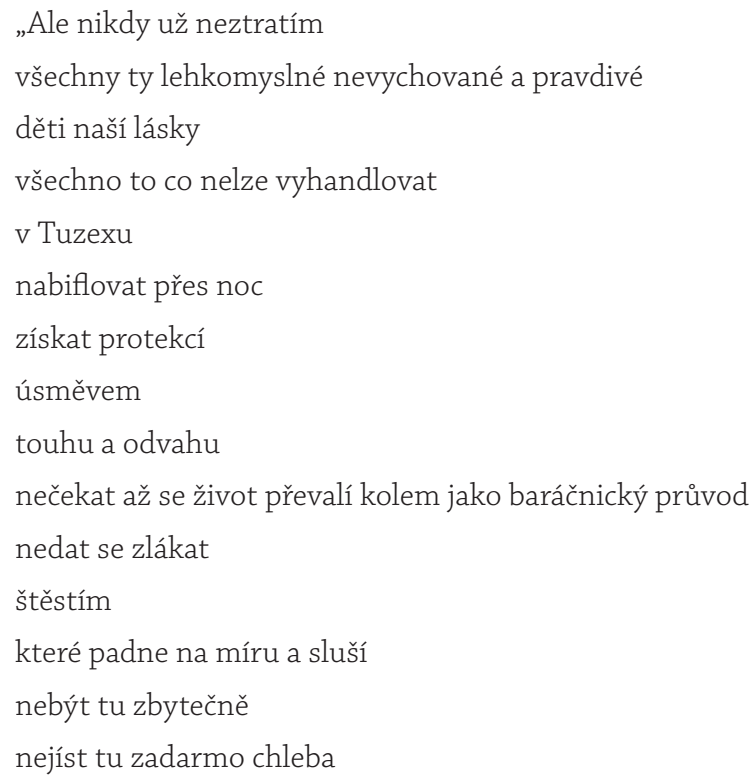

15) Rytmickým opakováním slov ve volném verši se zabýval také Jonathan Culler. Využil přitom báseň Fuga smrti od Paula Celana a prokázal, že působivého rytmu, ba přímo „omamného účinu, který si nás podmaňuje a přemáhá nás“, dosahuje tento text „neúprosným opakováním celých slov a slovních obratů, ne pouhých slabik“ (CULLER 2020: 199-200).

16) Srov. HOFFMANN 1994: 270. 
Uvidět ráno u Vltavy divoké koně

Vyjmenovat své lásky

a bude-li to třeba

nechat se zabít

pro ně“

(HRABĔ 1990: 46-47).

Úryvek zvolený $\mathrm{k}$ výuce však takovou příležitost žákům nenabídl. Důvody mi učitelka sdělila stručně ještě před začátkem hodiny:

„Mně se nejvíc líbí ta první část, měsíc vlající na obloze, slunce se uklání k západu, to je kouzelné a to se mi taky chtělo jim [žákům] ukázat."

\section{Návod k interpretaci}

Když se žáci v průběhu výuky setkali s básnickým úryvkem, museli své čtení takřka po celý čas podřizovat úkolům, které si učitelka připravila ještě před vyučovací hodinou a jejichž znění mělo povahu přesných, možná až přiliš striktních a nesmlouvavých formulací:

Úkoly:

1. Najdi v textu a vypiš:
a) metafory
b) personifikace
c) přirovnání
d) anaforu
e) oxymóron.
2. Napiš, kdo je hlavní postavou.
3. Vysvětli první sloku básně.

Snad proto by se dalo čekat, že komunikace ve vyučovací hodině bude stejně nekompromisní jako formulace úkolů $v$ přichystaném pracovním listu. Od chvíle, kdy učitelka vstoupila do třídy, dávala však jasně najevo, že chce, aby se výuka odehrávala v přátelské atmosféře a za součinnosti všech zúčastněných. Tento dojem nenarušovala ani skutečnost, že $v$ učebně bylo téměř třicet žáků a po většinu času měla výuka frontální formu - celá třída byla instruována 
k přečtení textu, učitelka následně kladla otázky všem žákům najednou a vyčkávala na jejich reakci:

Učitelka stojí u tabule, v ruce drží pracovní list s úkoly k textu Hrabětovy básně a mluví k celé tř́idě ( $v$ učebně uspořádané tradičně do tří řad lavic, v nichž jsou žáci usazeni ve dvojicích).

1 U: ((k celé třídě)) tak sme si přečetli tu báseň a máme tam k ní úkoly, péto ((obrací se k žákyni

2 ve druhé lavici)) můžeš nám přečíst zadání toho prvního?

3 D: ((tiše čte)) najdi v textu a vypiš metafory, personifikace, přirovnání, anaforu, oxy, ((opakuje))

4 oxymóron

5 Ž: =oxymorón, výborně, petul, děkuju ti, a ted’ se zeptám všech ostatních, dokážete tam něco

6 najít? tohle určitě zvládnete

7 D: (.) ((ticho ve třídě)) (no) tu personifikaci, manekýn

8 U: ((k žákyni, která odpověděla)) =no, výborně, výborně, perfektní, hani, slunce je překrásný

9 manekýn, je to zajímavé, že? a haničko, můžeš nám $k$ tomu textu ještě něco říct?

10 D: ((mlčí))

$11 \mathrm{U}$ : no, jestli bys k tomu ještě neřekla? (.) tak to nevadí, ale personifikace, no, co to je?

12 Ž: ((žák ve druhé lavici u okna)) no, to je to přenesení na věci.

$13 \mathrm{U}:$ ano, přenesení vlastností živých bytostí a osob na věci, jo?

14 Ž: jo, bytostí a osob na věci.

15 U: ano, bytostí a osob na věci. vidíte, jak vám občas ř́íám, to dáš, ne?

16 ((žertovně k žákovi ve třetí lavici u dveří, směje se))

17 Matěj: ((usměje se)) já vim, pani učitelko

$(23 / 11 / 2015 ; 5 \mathrm{CH}, 24 \mathrm{D}) \cdot{ }^{17}$

Situace, $v$ nichž probíhala komunikace o přečteném úryvku, tak mnohdy naznačovaly, že se učitelka snaží o to, aby žáky upoutala a motivovala k zájmu o téma hodiny: opakovaně je povzbuzovala $\mathrm{k}$ úvahám nad přečteným textem („tohle určitě zvládnete“, „a Haničko, můžeš nám k tomu textu ještě něco říct?“), průběžně zpřesňovala a doplňovala jejich reakce na položené otázky (řádky 8-9) a různými radami či nápovědami jim pomáhala $v$ tom, aby své reakce vhodně formulovali (řádky 13-15). Nelze přitom říci, že by se žáci stavěli k takové snaze zcela negativně a nechtěli s učitelkou spolupracovat (řádky 16-17). Ostatně

17) K přepisu zvukových záznamů vyučovacích hodin jsem zvolil transkripční systém, který se ukázal být relevantní v jiných dosavadních výzkumech mluvených interakcí učitelů a žáků ve frontální výuce (srov. TŮMA 2017). Pro přepis záznamu vyučovacích hodin používám výlučně malá písmena, z odchylek od ortoepické výslovnosti si všímám elize hlásek, redukované výslovnosti a protetických hlásek a zdomácnělá cizí slova zapisuji ortograficky (personifikace). Neverbální aktivitu zaznamenávám pouze tehdy, je-li potřebná pro interpretaci verbální činnosti (obrací se k žákyni). Přehled transkripčních značek je uveden v závěru článku. 
s uvedeným úsilím korespondoval také styl učitelčina mluveného projevu: nejednou se v její řeči objevovaly jazykové prostředky, jimiž se zřejmě snažila oživit výuku a pobavit žáky (překvapivými, neformálními obraty - „to dáš, ne?"), upoutat jejich pozornost (povzbuzením či pobídnutím k činnosti - např. 2. os. pl. ind. „tohle určitě zvládnete“) a získat si je vstřícnou, přátelskou a důvěrnou konverzací (iniciovanou využitím inkluzivního plurálu, familiárních výrazů, případně i zdrobnělin ve vokativech: „Petul““, „Hani“, „Haničko“).

Záznam vyučovací hodiny mi však současně ukázal, že ani snaha o vstřícnou komunikaci nebyla pro žáky natolik podnětná, aby v ní spatřili příležitost promluvit o tom, jak na ně báseň zapůsobila a zda si je něčím získala. V popředí jejich zájmu nestála totiž ani tak sama báseň jako spíše soustava úkolů, které byly $\mathrm{k}$ básni připojeny a s nimiž se žáci seznámili dříve, než si vưbec stačili verše přečíst. $Z$ promluv, které žáci pronášeli, když se věnovali básnickému úryvku, se pak mnohdy zdálo, jako by přichystané schéma zadaných úloh představovalo spolehlivý interpretační návod, který si v literární výchově vydobývá tak silnou autoritu, že si zvládne podřizovat vše, co lze o přečteném textu říci. A právě to možná rovněž vysvětluje, proč byly v průběhu výuky tolik oceňovány i promluvy žáků, kteří často jen odhadovali, co chce učitelka slyšet a co se hodí $\mathrm{k}$ doplnění jejích vět:

\footnotetext{
1 U: ((k celé třídě)) tak ty verše prkenně se uklání k západu, to je teda protimluv neboli

2 ((naznačuje žákům, aby její větu doplnili)) o-, oxy-

3 ŽŽ: ((odpovídá několik žáků najednou)) oxymorón

$4 \mathrm{U}$ : ano, oxymorón, správně, děkuju, moc dobře, řekli byste ještě k tomu něco?

5 ŽŽ: ((žáci mlčí))

6 U: tak jdeme dál ((nahlíží do textu))
}

\section{„Vysvětli první sloku básně“}

Ačkoli učitelka věnovala značné úsilí tomu, aby všechny ve třídě pobízela k vyjádření vlastního názoru na přečtený text, osnova přichystaných úkolů jí v této snaze kladla nejednu překážku. Mnohé promluvy, které jsem v hodině zaznamenal a které byly reakcí na zadané úkoly, vyvolávaly totiž dojem, že chtějí pouze vyhovět představě o přehledné kategorizaci přečteného textu a odmítají připustit jakoukoli okolnost, která by takovou představu mohla zpochybnit. 
Báseň se pak v zaznamenaných promluvách často jevila jako dílo, jehož výklad je snadno dosažitelný, zcela pochopitelný a jednoznačný:

1 U: ((k celé třídě)) tak otázka, kdo je hlavní postavou básně, co byste mi o ní řekli?

2 ŽZ̆: ((mlčí))

3 U: co byste mi o ní řekli, no, jaruš? ((pohlédne na dívku v poslední lavici))

4 D: $((m l c ̌ i ́))$

5 U: co byste mi řekli o hlavní postavě?

6 Ž: ((žák v druhé lavici)) no je to asi nějakej chlápek, co tak jako přemýšlí a ptá se sám sebe.

7 U: přemýšlí a ptá se sám sebe, jo?

8 Ž: ((žák v poslední lavici)) no jako někdo, kdo se bojí

9 U: myslíš, jako někdo, kdo se bojí? kdo má strach?

10 D: no, paní učitelko, jako že už je úplně vyděšenej

11 U: no, může to tak být, proč ne, (.) ale hlavně když říká to můžu tě ztratit, tak jako by se

12 ((naznačuje žákům, aby doplnili))

13 U: ((doplňuje vlastní výrok)) loučil, přece.

Jde o ukázku situace, která se $\mathrm{v}$ různých obměnách opakovala několikrát: učitelka sice povzbuzovala žáky k tomu, aby se neostýchali říct svůj názor („,o byste mi o ní řekli“), slibně vedený dialog ale nakonec převzala do svých rukou a na položenou otázku si odpověděla sama (,jako by se ... loučil, přece“). Dlužno však dodat, že se v dané situaci ani nenabízelo mnoho jiných možností, jak postupovat. I když se učitelka snažila citlivě posuzovat vše, co žáci o textu řekli, ve frontální výuce musela kontrolovat činnost celé třídy najednou a nezřídka čelila současně tolika nárokům na soustředění vlastní pozornosti, že jí nezbývalo nic jiného než najít způsob, jak snadno a rychle zhodnotit všechny promluvy, které v hodině zazněly („no, může to tak být, proč ne“).

$\mathrm{Z}$ přepsaného záznamu výuky se tak může zdát, jako by báseň podléhala nějaké šabloně. Ve chvíli, kdy byli žáci vybídnuti, aby v jejím úryvku našli metafory či personifikace, text využívali jako materiál sloužící pouze k identifikaci jasně definovaných kategorií. A když učitelka hovořila s žáky o tom, kdo je hlavní postavou básně, počínala si, jako by bylo nanejvýš užitečné hledat postavy či vypravěče tam, kde je vlastně spatřit nelze a kde ani žádný příběh vyprávěn není. Zkrátka a dobře: úlohy, které snad měly vzbudit naději, že dokážou vnímání poezie náležitě obohatit, nemohly být čtenářům o nic užitečnější než situace, které z poezie činí rutinu a povinnost. Svědčí o tom konečně i znění posledního, třetího zadání: „Vysvětli první sloku básně.“ Skrývají se v něm totiž rysy typické 
pro výuku, o níž se zmiňoval Jonathan Culler a která předpokládá, že básně čteme výhradně z toho důvodu, abychom jejich verše či sloky dokázali co možná nejpřijatelněji „vysvětlit“ (srov. CULLER 2020: 21). Není divu, že takový předpoklad vyvolal u žáků jen ostych a opatrné reakce:

1 U: ((k celé třídě)) no a poslední otázku tady máme, jak byste vysvětlili první sloku básně?

2 ŽZ̆: ((mlčí))

3 U: ((když nikdo neodpovídá, znovu vybízí k odpovědi)) no, jak byste vysvětlili tu první sloku?

4 Ž: ((váhavě)) asi jako že slunce zapadá?

5 U: no, jasně, perfektní

\section{Úskalí formalismů}

V zaznamenané vyučovací hodině lze jen sotva spatřit to, o čem se mi kolegyně zmiňovala, když upozorňovala na svůj silný vztah k poezii Václava Hraběte. Zatímco v průběhu rozhovoru několikrát zdůraznila, že je docela přirozené, když se člověk ponoří do četby veršůn, nechá se strhnout obrazností slov a kolébat svůdnou melodií básnického textu (aniž se podrobněji stará o jeho kompozici, jazyk, styl či tematickou výstavbu), ve vyučovací hodině se mi takové čtenářské zaujetí nedařilo postřehnout a spíše jsem se opakovaně ocital v situacích, v nichž se od žáků vyžadovalo, aby dosazovali správná slova do nevyplněných políček pracovního listu. Jinak řečeno: místo toho, aby báseň zapůsobila na čtenáře svou obrazností a podmanivým rytmem, její úryvek sloužil leda k evidenci jevů, které byly předem definovány a zakotveny $\mathrm{v}$ představě jakéhosi obecně platného interpretačního klíče.

Je přitom paradoxní, že veškeré úkoly, které se v hodině vztahovaly $\mathrm{k}$ básnickému úryvku, volila učitelka $v$ dobré viřre - s přesvědčením, že především takto dokáže pobídnout žáky $\mathrm{k}$ práci s textem a směřovat je $\mathrm{k}$ rozmanitým složkám jeho výstavby. Postupy, které za tímto účelem využila, vyvolávají však tolik otázek, že dokážou i nestranného pozorovatele přimět k pochybnostem, zda taková setkání s poezií jsou pro žáky skutečně užitečná a zda jim poskytují dostatek příležitostí $\mathrm{k}$ tomu, aby je básnické texty upoutaly a získaly si jejich pozornost. S odstupem několika let - po desítkách hodin strávených zúčastněným pozorováním výuky v různých školách - jsem se v těchto pochybnostech jen utvrdil. Ještě mnohokrát jsem zažil vyučovací hodiny, v nichž mi připadalo, jako by bylo nanejvýš oprávněné tvrdit, že se každá báseň dá uspokojivě nahradit nějakou 
stručnou parafrází, a jako by se zárukou seriózního přístupu k poezii mohlo stát jedině členění textu na prvky či složky, které stačí mechanicky zařazovat do pevně ohraničených kategorií. ${ }^{18} \mathrm{~A}$ stejně tak jsem si v pozorovaných hodinách všímal, že usilovným pátráním po jediném správném výkladu dílčích jevů, které se v básni dají rozlišit, se může docela snadno a nenápadně vytratit touha k hledání odpovědí na otázku, proč vůbec poezii čteme. Tedy i na otázky, zda jsme schopni poezii ocenit nejen pro sdělnost či srozumitelnost, ale také pro nepoddajnost a mnohoznačnou znepokojivost, jež z některých básní činí jedinečné a neopakovatelné řečové události.

Rozhovor s kolegyní mě však zároveň přesvědčoval, že v úvahách o vyučování poezie rozhodně nelze nechávat stranou ani to, co učitelé vypovídají o vlastním, osobním vztahu k básním. Opakovaně se mi totiž ukázalo, že prostřednictvím takového čtenářského zaujetí, o němž mluvila učitelka Jana, se ony důvody docela přirozeně a samovolně hlásí ke slovu. Znovu se tak vracím $\mathrm{k}$ úvodu tohoto článku. Stejně jako v rozhovoru, který jsem s učitelkou vedl, se totiž i v Cullerově knize lze celkem snadno přesvědčit, že ne všechny básně je užitečné chápat jako objekty určené $\mathrm{k}$ interpretaci. A je pro čtenáře někdy daleko výhodnější, když se k básni opakovaně ${ }^{19}$ vracejí, připomínají si ji a vychutnávají si potěšení z jejích rytmů a slov, než aby se pokoušeli za každou cenu pátrat po tom, kdo a v jaké situaci $v$ básni promlouvá: ${ }^{20}$

„Dalším cílem knihy je utkat se s jedním podle mne zbytečným předpokladem velké části teorie a pedagogiky lyriky, totiž s míněním, že lyriku čteme proto, abychom podali novou interpretaci. $V$ dějinách poezie jde o celkem nedávný posun. $V$ dřívějších staletích čtenáři od básní očekávali poučení a potěšení; interpretace, jaké se dnes považují za důkaz seriózního zaobírání se textem, se po studentech nevyžadovaly. Mohlo se po nich chtít, aby báseň rozčlenili, napodobili, přeložili,

18) Úryvky ze záznamu hodiny učitelky Jany jsem zde využil jako příklad těch situací, s nimiž jsem se opakovaně setkával jak na základních, tak na středních školách. Na některé z těchto situací jsem odkazoval už před lety v disertační práci (JINDRÁČEK 2015). A ještě o něco podrobněji se na ně zaměřím v knize, kterou nyní připravuji k vydání.

19) Klíčový je pro Cullera pojem „rituální či ,ritualistické‘ dimenze lyriky, jak jej formuluje Roland Greene“. Podle Cullera je totiž lyrika „vystavěna tak, aby umožnila opakování“ (CULLER 2020: 149-150). A zásadní roli v lyrické tradici hraje epideiktická složka lyriky, pro niž je důležitý jazyk jakožto akce. Ne však taková, která utváří fikci: lyrika neustavuje „fikční svět pomocí performativů, jako to údajně činí romány, nýbrž pronáší výpovědi (doslovné či figurativní) o našem světě“ (IBID.: 155). Oporu Cullerovi představuje Hegelova lyrická teorie v pojetí Käte Hamburgerové.

20) Což je princip, který se podle Cullera stal základem mnoha světově proslulých a vlivných učebnic literatury (např. ARP - JOHNSON 2013: 27, VENDLER 2002), které instruují studenty k tomu, aby každou báseň vykládali jako „fikční promluvu“, zpravidla bez ohledu na to, oč si básnický text ř́íá a zda je pro něj takový postup vůbec vhodný (CULLER 2020: 8, 134). Jde o princip, který je podle Cullera smysluplný jen u malého počtu básní (tř̌eba u krajních subžánrů lyriky - dramatického monologu a balady), a i tam, kde je mluvčí básně nějak signalizován, se mnohem důležitější jeví momenty, které posilují vnímání básně jako události (lyrické oslovení, hyperbola, lyrický prézens, rytmus, souzvučnost rýmu, asonance nebo aliterace). 
naučili se ji nazpamět, ocenili ji nebo v ní rozeznali různé aluze a rétorické či prozodické strategie avšak interpretace v moderním smyslu slova se stala součástí setkávání s literaturou až ve 20. století [...]“ (CULLER 2020: 21).

Culler má na mysli především praxi vnucenou „angloamerickou novou kritikou" a jejím předpokladem, že básně čteme proto, abychom podali novou interpretaci. Nezastává přitom vyhraněný postoj, který by jakoukoli interpretaci zcela odmítal (už zjištování, co je na poezii lákavé, v sobě přece analýzu zahrnuje), ale vyjadřuje názor, že „interpretace“ může být jen jedním „z potěšení, které lyrika skýtá“, a nikdy se nejedná o nezbytný předpoklad setkání s poezií (CULLER 2020: 21). Podle Cullera je totiž pro čtenáře daleko přínosnější, když neusilují o univerzální návod jak definovat a interpretovat básnické texty, ale vnímají rozmanitost lyrické poezie a sami hledají přístup $\mathrm{k}$ „potěšení z jejích rytmů, zvukových vzorců, verbálních her či imaginativní energie“ (IBID.: 12). Což se nakonec ukázalo i v zaznamenané hodině, když se ani přes značné úsilí nedařilo učitelce motivovat žáky alespoň k tomu, aby krátce sdělili, jak na ně báseň zapůsobila a zda si něčím získala jejich pozornost.

V záznamu výuky se tak naskytlo několik přiležitostí, jak se přesvědčit, že ani ve školním prostředí není chybou, když se čtenáři odmítají spolehnout na jeden univerzálně správný způsob interpretace básní. A že rozhodně nemusí být od věci, když si všimnou, zda určitá ustálená a zdánlivě osvědčená interpretační praxe umožňuje vnímat a oceňovat různé druhy svůdných efektů, jichž je poezie schopna. Ostatně tentýž názor vyjadřují i knihy, na něž se Culler několikrát odvolává. V práci Lyric Powers (2008) Roberta von Hallberga si Culler všímá pasáže, která uvádí, že básníci od čtenářů nevyžadují interpretaci a jejich díla mohou dosáhnout úspěchu i bez toho, aby byla (přinejmenším v průběhu četby) jakkoli doplňována či vysvětlována (HALLBERG 2008: 4). ${ }^{21} \mathrm{~A} z$ knihy Susan Stewartové Poetry and the Fate of the Senses (2002) přebírá část, v níž se říká, že básně si nevybavujeme jakožto fakt, nýbrž je registrujeme s tím, že umožňují připomenutí, nové vyslovení, nové prožití:

„[...] i když si vzpomínáte jen na několik slov, někdy (a je to k zbláznění) dokonce jen na rytmus, je tu př́slib události, který lze v prézentu artikulace zreprodukovat“" (CULLER 2020: 429). ${ }^{22}$

21) Culler však nesouhlasí s tvrzením Roberta von Hallberga, že „před lákavostí poezie pro oko ducha a sluch těla se má zastavit veškerá analýza" (CULLER 2020: 428).

22) Srov. STEWART 2002: 104: „I propose that the sound of poetry is heard in the way a promise is heard. A promise is an action made in speech, not in the sense of something scriptable or repeatable, but something that ,happens,' that ,occurs' as an event and can be continually called upon, called to mind, in the unfolding present." 
I když se tyto názory neobešly bez kritických reakcí (např. STRIER 2017) a Cullerovi bylo vytýkáno, že svou práci vystavěl na nesourodém materiálu, který leccos podstatného opomíjí (FRANZ 2016, PERLOFF 2016), přínos knihy pro interpretaci dění ve výuce poezie je podle mého mínění nezpochybnitelný. Jistě by se dalo polemizovat o tom, zda Culler až př́liš nezastiňuje některé teorie, jejichž význam se v úvahách o lyrice už mnohokrát prověřil. ${ }^{23}$ Srovnání se záznamy, které se mi ve škole podařilo získat, ale naznačuje, že tím nejcennějším, co Teorie lyriky přináší, není ani tak diskuse s jinými pohledy na lyriku jako spíše odvaha, s níž se Culler vydává proti interpretační praxi, která se (jak jsem se v průběhu výzkumu sám přesvědčil) ve školní výuce ustálila a vžila skoro jako samozřejmý předpoklad čtení poezie. ${ }^{24}$ Cullerova kniha totiž dokazuje, že při čtení básní nejsou ani učitelé oprávněni být arbitrem jediné a neměnné pravdy (srov. MARKOVÁ 2020a). A varuje, že právě ve škole - snad ještě nápadněji než kdekoli jinde - mohou nastat situace, které čtenářům sice nabízejí příležitost k setkání s básnickým textem, ale ve skutečnosti jim nepřinášejí nic užitečného a mnohem spíše odvádějí jejich pozornost od toho, co je na poezii zvláštní a jedinečné. At' už je tato jedinečnost dána mimořádnými zvukovými (rytmickými) účinky. Anebo jinými („rituálními“) prvky, které z básní činí přítomné řečové události, hodné toho, abychom si je uchovávali v paměti, opakovaně se k nim vraceli a připomínali si je - třeba právě tak, jak to zcela spontánně vyjádřila učitelka v úvodním rozhovoru.

\section{Místo závěru: inspirace a paralely}

Když se Josef Hrdlička v roce 2018 vyjadřoval k anglickému vydání Cullerovy knihy, uvedl, že Teorie lyriky „může podnítit celkem sporadické teoretické psaní o lyrice (resp. poezii) a základní debatu, která tu citelně chybí“ (HRDLIČKA 2018: 433). Konstatoval přitom, že jediné srovnatelné, fakticky ale osamocené

23) Tak např́klad Eva Zettelmannová vytýká Cullerovi, že až př́liš zastiňuje otázku fikčnosti (tedy i lyrického subjektu) a že se přezíravě staví ke všemu, čím by naratologie mohla teorii lyriky obohatit (ZETTELMANN 2017: 196, srov. HRDLIČKA 2018: 432-433). A pochybnosti o některých částech Cullerovy knihy byly vyjádřeny i v českém prostředí. Třeba podle Iva Pospiśsila Cullerův náhled na teorii žánrů neodpovídá takřka ničemu z toho, co teorie žánrů a koneckonců ani genologie jako samostatná disciplína postulovaly posledních padesát let. Proto se Pospíšilovi „nelíbí ani označení lyriky za žánr" (POSPÍŠIL 2020: 175).

24) Že se jedná o aktuální téma, dokazuje třeba nedávno vydaný esej Martina Pokorného. Výmluvná je zejména jeho polemika s „institucionálním, takřka neosobním vyzněním“ maturitních testů z literatury: „Následování osnovy, podle níž se má chvíli mluvit o kompozici, chvíli o čase a prostoru, chvíli o postavách a chvíli o motivech, může vést leda k vyvolání dojmu snaživce, který se naučil učebnici nazpamět a dvě príručky k tomu - a přesto nemáme jistotu, zda dílo, o němž hovoří, opravdu přečetl, a pokud ano, zda mu něco řeklo" (POKORNÝ 2020). 
(nepočítají-li se „starší práce Pražské školy a ojedinělé, spíše dílčí studie dalších autorů") zůstávají v českém prostředí práce Miroslava Červenky. Necháme-li totiž stranou Červenkovy Fikční světy lyriky (ČERVENKA 2003), rozvijející především teorii lyrického subjektu (vůči níž se Culler staví polemicky), některé starší Červenkovy práce mají k Teorii lyriky docela blízko a úvahami o rytmu, verši a fiktivnosti (resp. o jejich vlivu na charakteristiku poezie a prózy) ${ }^{25}$ ji mohou snadno připomenout (např. ČERVENKA 1993, 1996; srov. také HRDLIČKA 2020: 435). ${ }^{26}$

Domnívám se však, že není od věci upozornit na řadu dalších českých publikací, jejichž témata nejsou od některých úvah Teorie lyriky daleko. ${ }^{27}$ Snad nejlépe to podle mého soudu vystihují studie Zdeňka Kožmína. Stačí připomenout proslulý úvod Umění básně (KOŽMíN 1990), inspirovaný otázkami „Čím je báseň velká?“ a „Kdy se pro nás stává naplno básní?“ (IBID.: 5-13). Když se zde Kožmín odvolává na knihu Čistá poezie (1935) Henriho Bremonda a cituje slova, která mají v čtenářích probudit touhu nechat se „poezií okouzlit“ a naslouchat „její slovní magii“, ${ }^{28}$ vyzdvihuje totéž, co Jonathan Culler oceňuje na půvabu rituální dimenze básní:

„Rituální složky - právě coby eminentně svůdné - nejsou tak docela solidní, dokonce mohou vyvolávat rozpaky. Baudelaire mluví o čarodějnictví, Mallarmé se dovolává magie [...] Pokud položíme zvláštní důraz na apostrofní oslovení, jež predpokládá oživlý svět, který lze žádat, aby konal, nebo se činu zdržel, implicitně tím spojujeme lyriku s magií, okouzlováním světa: světa obývaného vnímajícími mocnostmi, světa předtím, než z něj prchli bozi“ (CULLER 2020: 427). ${ }^{29}$

25) Nápadné shody s Červenkovou statí lze nalézt např́ílad i tam, kde Culler piše, že základní charakteristikou lyriky „není popis a interpretace nějaké minulé události“, nýbrž „iterativní a iterovatelná performance události v lyrické prrítomnosti“. Podobně se vyjadřuje i Červenka, když uvádí, že v rytmu lyriky se strofy opakují jako navzájem ekvivalentní, simultánní celky, takže vnímání času „je tu už zcela deformováno“ a „celá báseň stojí před námi v jediném Ted"' (ČERVENKA 1996: 109).

26) Andrea Králíková upozorňuje také na „možné korespondence“ Cullerova pojetí tzv. triangulárního oslovení (kdy se skrze oslovované či oslovovaného v básni cítí osloven sám čtenář či posluchač) s Červenkovým „Sebeoslovením v lyrice“" (KRÁLÍKOVÁ 2021: 164).

27) Zajímavé české paralely ke Cullerově koncepci lyriky nachází také Ivo Pospíšil v poslední knize Pavla Jiráčka Od slov klyrickému vědomí (2020). K tomu srov. POSPÍŠIL 2020: 176-177.

28) Kožmín však výslovně uvádí, že velikost básně nespočívá jen v jejím „magickém“ účinku, ale leží v průsečíku tří př́stupů: „velká báseň nás musí nepochybně fascinovat, musí být zralým, strukturovaným uměleckým tvarem a konečně musí být nasycená živou zkušeností, obrácená k hlubinám lidského života" (KOŽMíN 1990: 8).

29) Stejně jako Kožmín ani Culler se nespoléhá jen na slovní magii, která si čtenáře básní podmaňuje. Zdůrazňuje, že lyrika usiluje též se vší elegancí o uspořádání jazykového materiálu, jehož přitažlivost vyžaduje jiné jméno než okouzlení, a společně s Klasem Moldem tvrdí, že lyrika „reguluje rovnováhu mezi okouzlením a deziluzí, úžasem a střízlivostí, a činí to ve světě, jenž má neustálý deficit v jednom nebo ve druhém směru“. Lyrika se tedy věnuje „též velice přízemnímu svádění pomocí kombinací písmen, zvuků a ticha“ (CULLER 2020: 428). 
A podobně když na několika místech své knihy Culler uvádí, že „interpretace“ - přestože jde o jedno „z potěšení, které lyrika skýtá“ - není nezbytným předpokladem setkání s poezií (např. CULLER 2020: 12, 14, 21-22), jako by se v jeho tvrzeních ozývala slova, jimiž Kožmín vyvrací domněnku, že je zapotřebí sáhnout po básni jako po něčem, co je nutno za všech okolností interpretovat:

„Nepovažujeme interpretaci za žádné absolutno v našem vztahu k jednotlivým básním, k poezii. Vždyt interpretace je hlavně zracionalizováním fenomému, který racionalitu pouze zahrnuje jako svưj dílčí moment. Každá báseň i tu nejdokonalejší interpretaci přesahuje“ (KOŽMíN 1990: 13).

Jinak řečeno: každá báseň si sama vynucuje určitý způsob čtení30 a stává se pro čtenáře naplno básní, když pro něj něco podstatného znamená, když vstupuje do jeho vlastní řeči a je „inspirací jeho niterného života“:

„Báseň je vždy děním, také děním významů, do nichž se promítá tolik dalších významů z nás, kdo báseň čteme, z doby, do níž báseň vstupuje, ze samotného básníkova tvưrčího zápasu, že se v každé básni ocitáme spíše v průsečíků mnoha sil, do jejichž působení jsme vtaženi“ (KOŽMíN 1990: 12).

Opět slovy Jonathana Cullera: lyrická báseň je pro svého čtenáře mnohem spíš přítomnou událostí než její reprezentací. Nebo jinak řečeno: „[v] básni se nemusí nic dít, jelikož děním má být sama báseň“ (CULLER 2020: 277).

Přestože se tedy Teorie lyriky řadí $\mathrm{k}$ aktuálním publikacím, které v posledních letech zejména $\mathrm{v}$ anglofonním prostředí oživily zájem o lyrickou poezii, ${ }^{31}$ zdá se mi, že její závěry nejsou v českém prostředí něčím zcela novým a převratným. ${ }^{32}$ Ostatně nebude tomu jinak, když Teorii lyriky srovnáme s úvahami, v nichž se

30) Proto Kožmín píše: „nejoptimálnější př́stup k básni vidíme v naslouchání tomu, co text básně skutečně říká.“ A proto je podle něj potřeba, abychom si při setkánís poezií „našli opěrné body, které nám umožní $\mathrm{k}$ tomuto významovému koncentrátu pronikat" (KOŽMíN 1986: 8). Pozoruhodný př́klad takového př́stupu k sémantice básnického textu lze přitom vidět $\mathrm{v}$ kategoriích prostoru a času. Ty se Kožmínovi opakovaně stávaly vyššími významovými rovinami, v nichž se čas a prostor spojují s jazykem, stylem, veršovou výstavbou, žánrem apod. (TLUSTÝ 2016: 70). Což je podle Andrey Králíkové další paralela s Cullerovou knihou, zejména s kapitolou, která se zaobírá časovostí lyriky a její spojitostí s prézentem: „Jakkoli může tato zmínka [v Cullerově knize] vyznít okrajově, obdobnou stopu lze nalézt v českém kontextu v pracích Zdeňka Kožmína, který píše o estetickém osvojování zkušenosti skrze zkušenost s časem a jeho modelováním“ (KRÁLÍKOVÁ 2021: 165).

31) O tom, že v literární vědě nastává „obrat" $k$ poezii a k lyrice, hovoří například SHAW 2016. Své závěry přitom opírá o publikace vydané v posledních letech (WHITE 2014, JACKSON - PRINS 2014, CULLER 2015). V češtině $\mathrm{k}$ tomu srov. HRDLIČKA 2018, 2020.

32) Jistě by se dalo upozornit na mnohé rozdíly v tom, jak Kožmín a Culler nahlížejí na interpretaci básnického textu: zatímco Kožmín konstatuje, že „interpretace textu je v podstatě jeden a týž proces, at' [...] probíhá veřejně nebo v intimitě našeho obeznávání textu“ (KOŽMíN 1995: 571), Culler prohlašuje, že „básníci od čtenářů nevyžadují interpretaci“ a je krajně nevýhodné považovat básně „za objekty k interpretaci“ (CULLER 2020: 12). Zde mě však zajímají především zjevné paralely, které lze mezi myšlenkami obou autorů spatřit. 
Kožmín soustředil na práci s básní ve škole a kde představil vlastní metodické návrhy pro výuku poezie (KOŽMíN 1986). Právě tak jako se v Cullerově knize zpochybňuje platnost vžitých pedagogických návodů k interpretaci lyriky, ani Kožmín nehodlá svým čtenářům nabídnout zaručeně úspěšný způsob, jak „snadno a rychle provést rozbor básně“ (IBID.: 5). A když se Kožmín věnuje textům třinácti různých autorů (IBID.: 15-131), nespoléhá se na jedinou metodu jejich výkladu a detailním čtením textu - obdobně jako Culler - dává najevo, že interpretace pro něj nikdy není mechanickou záležitostí, která by konkrétní dílo jen přizpůsobovala nějaké šabloně (srov. TLUSTÝ 2016: 58-59).

Paralely, které se zde dají zahlédnout, mě proto utvrzují v přesvědčení, že Cullerova kniha dokáže být aktuální výzvou k debatě o přehodnocování vžitých pohledů na lyriku a poezii, stejně jako je schopna podněcovat k hledání souvislostí s tématy, která v naší literární teorii rezonovala už před několika desítkami let. ${ }^{33}$ Mnohé Cullerovy postřehy o konstitutivních rysech lyriky tak mají v českém prostředí nač navázat. A ve světle situací, jejichž příklady jsem do tohoto článku zařadil, mohou (společně s knihami Zdeňka Kožmína) představovat i cennou reakci na současné hlasy volající po takovém učebním prostředí, které poskytuje příležitost $\mathrm{k}$ soustředěnému a trpělivému čtení básní a v němž se jednotlivci nebojí projevit své názory, chybovat a zkoušet různé cesty k poezii (srov. MARKOVÁ 2020a, POKORNÝ 2020). Cullerova Teorie lyriky patří totiž k těm ojedinělým knihám, které dokážou dnešním čtenářům objasňovat, proč je pro ně užitečné, aby dbali o vlastní „potěšení“ z lyrických básní (CULLER 2020: 428). ${ }^{34}$ A proč je důležité, aby se zbavovali zbytečného ostychu před poezií a nabývali sebevědomí k překonávání rozpaků nad neodbytnými otázkami, zda lze básním plně porozumět a zda v nich přece jen není něco víc, než je člověk schopen odhalit. ${ }^{35}$

33) Konečně, sám Culler v předmluvě k českému vydání knihy konstatuje, že už ve své disertaci byl inspirován myšlenkami Romana Jakobsona a pražské školy, a třebaže se nakonec zaměřil na strukturalismus ve Francii, některé podněty pro vznik Teorie lyriky získal právě v pracích z třicátých let.

34) Podle Cullera by cílem takové výuky mělo být něco podobného, co je běžné při setkání s písní, když zjištujeme, co se nám líbí a co ne a „získáváme povědomí o tom, jak a čím si jsou blízcí různí zpěváci a skladatelé i různé druhy hudby“. Jde především o to, „dbát o své potěšení [z četby lyrických básní] a současně nabývat sebejistoty, pokud jde o vlastní schopnost vyhodnocení, co vlastně upoutalo naši pozornost“ (CULLER 2020: 428).

35) Článek vychází z materiálu, který rovněž využívám v chystané knize o poezii v českých školách. Ani jedna z těchto publikací by však nevznikla, nebýt učitelek a učitelů ochotných podílet se na několikaletém výzkumném šetření. Vděčím jim především za to, že mi s obdivuhodnou trpělivostí umožňovali, abych byl př́tomen situacím, které provázejí jejich každodenní nelehkou práci. 


\section{PŘEHLED TRANSKRIPČNÍCH ZNAČEK}

(srov. ČMEJRKOVÁ - JÍLKOVÁ - KADERKA 2004)

U, Ž, ŽZ̆, D, CH označení mluvčí/ho (U = učitel, Ž = žák, ŽŽ = žáci, D = dívka, CH = chlapec)

$=\quad$ okamžité navázání na předchozí repliku

znovu zdůraznění slabiky/slova

a:le: protažení hlásky

e ee eee eh ehm em hezitační a responzní zvuky

(.) krátká pauza

(..) delší pauza než 1 sekunda

? $\quad$ vysoké stoupnutí hlasu

, mírné stoupnutí hlasu

. klesnutí hlasu

nedok- nedokončení slova

<praštil> pasáž pronesená se smíchem

(jen) předpokládaný, ne dobře srozumitelný výraz

() nesrozumitelný výraz

((směje se)) komentár̆ přepisovatele

... vypuštění části transkriptu

\section{PRAMEN}

HRABĚ, Václav

1990 Blues pro bláznivou holku (Praha: Československý spisovatel)

\section{LITERATURA}

ARP, Thomas - JOHNSON, Greg (eds.)

2013 Perrine's Sound and Sense (New York: Cengage)

BASSEY, Michael

1999 Case Study Research in Educational Settings (Buckingham: Open University Press)

\section{CULLER, Jonathan}

2015 Theory of the Lyric (Cambridge, Massachusets/London: Harvard University Press)

2020 Teorie lyriky, přel. M. Pokorný (Praha: Karolinum)

\section{ČERVENKA, Miroslav}

1993 „Sebeoslovení v lyrice“, in D. Hodrová (ed.): Proměny subjektu I. (Praha: Ústav pro českou literaturu AV ČR) 
Václav Jindráček

Výuka poezie a inspirace Cullerovou Teorií lyriky

1996 „Verš a poezie“, in týž: Obléhání zevnitř (Praha: Torst), s. 79-113

2003 Fikční světy lyriky (Praha: Paseka)

ČMEJRKOVÁ, Světla - JíLKOVÁ, Lucie - KADERKA, Petr

2004 „Mluvená čeština v televizních debatách: korpus DIALOG“, Slovo a slovesnost 65, č. 4, s. 243-269

EVA-WOOD, Amy L.

2008 „Does feeling come first? How poetry can help readers broaden their understanding of metacognition“, Journal of Adolescent \& Adult Literacy 51, č. 7, s. 564-576

FRANZ, Paul

2016 „Burden of Proof. On Jonathan Culler's Theory of the Lyric (Harvard, 2015)“, PN Review XLII, č. 227, s. $15-18$

HNÍK, Ondřej

2014 Didaktika literatury: výzvy oboru (Praha: Karolinum)

HRDLIČKA, Josef

2018 „Cullerova Teorie a problémy lyriky“, Česká literatura 66, č. 3, 2018, s. 423-437

2020 „Doslov k českému vydání”, in J. Culler: Teorie lyriky (Praha: Karolinum), s. 431-438

JACKSON, Virginia - PRINS, Yopie (eds.)

2014 The Lyric Theory Reader (Baltimore: John Hopkins University Press)

JINDRÁČEK, Václav

2015 Možnosti didaktické interpretace epické a lyrickoepické poezie na základní škole. Disertační práce (Ústí nad Labem: Univerzita J. E. Purkyně)

KOŽMíN, Zdeněk

1986 Interpretace básní (Praha: SPN)

1990 Umění básně (Brno: K22a)

1995 [1994] „O interpretaci. Otázky Jiřího Holého pro Zdeňka Kožmína“, in týž: Studie a kritiky (Praha: Torst), s. 566-572

KRÁLÍKOVÁ, Andrea

2021 „Cullerova Teorie lyriky a návraty k poezii“, Slovo a smysl 18, č. 36, s. 161-167

LESSLEY, Shara

2014 „Beyond Metrophobia, or I, too, dislike it“, West Branch 76, s. 95-112

MÁCL, Ondřej

2020 „Co dělá báseň, která oslovuje vítr?“, itvar.cz [online] prosinec 2020 [citováno 16. 7. 2021]. Dostupné z: https://itvar.cz/co-dela-basen-ktera-oslovuje-vitr 
MARKOVÁ, Eva

2020a „Od abstinence k recidivě. Didaktika lyriky a role tvůrčího psaní ve výuce“, A2 kulturní čtrnáctideník XVI, č. 15, s. 6

2020b „Obcovat s básněmi. Poznámky k Teorii lyriky Jonathana Cullera“, A2 kulturní čtrnáctideník XVI, č. 22, s. 4

PERLOFF, Marjorie

2016 „Jonathan Culler, Theory of the Lyric“, Nineteen Century Literature LXXI, č. 2, s. 256-261

PESKIN, Joan

2007 „The genre of poetry: Secondary school student's conventional expectations and interpretative operations", English in Education 41, č. 3, s. 20-36

PIKE, Mark

2000 „Pupils'poetics“, Changin English: Studies in Reading \& Culture 7, č. 1, s. 45-54

POKORNÝ, Martin

2020 „Mezi výkladní skřriní a cihlou. Jak ve výuce vrátit hlas básníku i básni“, A2 kulturní čtrnáctideník XVI, č. 15 , s. 4

POSPÍŠIL, Ivo

2020 „Kniha o lyrice jako koncepce, výzva a malé americko-české srovnání“, Slavica Litteraria 23, č. 2, s. 173-177

ŘĚ̌ICHOVÁ, Vlasta - VALA, Jaroslav - SLADOVÁ, Jana

2014 „Poetry in School the Old Issues and New Challenges“, E-Pedagogium 14, č. 4, s. 127-139

SHAW, Lytle

2016 „Framing the Lyric“, American Literary History 28, č. 2, s. 403-413

STEWART, Susan

2002 Poetry and the Fate of the Senses (Chicago: University of Chicago Press)

STRIER, Richard

2017 „A Lover’s Journal“, Modern Language Quarterly 78, č. 1, s. 111-112

TIMOTHY, Alexander Essien

2018 „The Ezekiel strategy: prevention and cure for metrophobia“, Education Extracts 6, č. 2, s. 96-105

TLUSTÝ, Jan

2016 „Zdeněk Kožmín a umění interpretace“, Bohemica Litteraria 19, č. 2, s. 55-73

TRÁVNÍČEK, Jiří

2017 Česká čtenářská republika. Generace, fenomény, životopisy (Brno: Host) 
Václav Jindráček

Výuka poezie a inspirace Cullerovou Teorií lyriky

TŮMA, František

2017 „Stř́dání kódů ve výuce angličtiny u učitelů-expertů pohledem konverzační analýzy“, Slovo a slovesnost 78 , č. 4, s. 283-304

VALA, Jaroslav

2013 Poezie, studenti a učitelé. Recepce, interpretace, výuka (Olomouc: Univerzita Palackého)

VENDLER, Helen

2002 Poems, Poets, Poetry (Boston: Bedford/St. Martins)

VON HALLBERG, Robert

2008 Lyric Powers (Chicago/London: The Chicago Universtity Press)

WHITE, Gillian

2014 Lyric Shame. The "Lyric“ Subject of Contemporary American Poetry (Cambridge, Massachusets/London: The Belknap Press of Harvard University Press)

YIN, Robert K.

2003 Case Study research: design and methods (Thousand Oaks: SAGE Publications)

ZETTELMANN, Eva

2017 „Apostrophe, Speaker Projection, and Lyric World Building“, Poetics Today XXXVIII, č. 1, s. 189-201

PhDr. Václav Jindráček, Ph.D., vaclav.jindracek@ujep.cz, Katedra bohemistiky, Pedagogická fakulta Univerzity Jana Evangelisty Purkynè, Ústí nad Labem, Česká republika / Department of Czech Studies, The Faculty of Education, University of Jan Evangelista Purkyně, Ústí nad Labem, Czech Republic

Toto dílo Ize užít $v$ souladu s licenčními podmínkami Creative Commons BY-NC-ND 4.0 International (https://creativecommons.org/licenses/by-nc-nd/4.0/legalcode). Uvedené se nevztahuje na díla či prvky (např. obrazovou či fotografickou dokumentaci), které jsou v díle užity na základě smluvní licence nebo výjimky či omezení příslušných práv. 